\title{
Regional Disparities in Urban Population Access to Sanitation Services. Case Study: Romania
}

\author{
Florin - Constantin Mihai \\ Andreea lămăȘanu
PhD. Students, Faculty of Geography and Geology, "Alexandru loan Cuza "University, lasi,Romania mihai.florin86@yahoo.com \\ Liviu Apostol \\ Prof. PhD., Faculty of Geography and Geology, \\ "Alexandru loan Cuza "University , lasi,Romania
}

\begin{abstract}
Sanitation services still not fully cover the urban population and this leads to different types of pollution and affects the urban landscape. This paper aims a geographical approach by highlighting territorial disparities in the Romanian counties regarding the urban population access to waste collection services and to examine the environmental issues. Statistical database processed by ascending hierarchical cluster analysis are mapped at the level of Romanian counties achieving a spatial-temporal analysis for the period 20032008. The paper also discuss about the current dysfunctions existing in urban waste management from Romania. Development of waste management facilities are in the process of transition from a traditional system based only on landfilling towards an integrated waste management system which develops the recycling and recovery of waste generated. Romania as an EU member country must improve the quality of sanitation services. Each city must provide the full collection of municipal waste generated in order to eliminate the illegal dumping.
\end{abstract}

Keywords: waste management, sanitation services, urban population,territorial disparities

\section{Introduction}

Urban waste management is still a major environmental issue in developing countries (Kanat, 2010; Chen, 2010; Firdaus and Ahmad, 2010) and the limited access of urban population to sanitation services leads to illegal dumping of uncollected waste.In addition, the new Member States of the EU-27 do not have full coverage of population to waste collection services, especially in rural areas. Legislative changes due to adoption of the Eu acquis have direct implications on waste collection services from urban areas (Marques and Simoes, 2008; Ventosa 2008). National, regional and local authorities need to obey the new rules, to review and monitor the waste management plans.Private sector is increasingly involved in carrying out activities of collection, transportation and landfill of urban waste.Socioeconomic,demographic and geographic disparities at national, regional or local level are reflected in waste management systems adopted. Thus, there are differences in the efficiency of the instruments and policies adopted concerning waste collection services in different regions of Europe (Gellynck and Verhelst 2007; Dahlén 200,Manzzati and Roboli 2008, Mengozii 2010).Urban population from Romania is not fully covered by the public sanitation services as well as in most of the new EU-27 Member States.Because of this, illegal dumping of waste is occuring in the cities proximity. Full access of urban population to waste collection services is a basic condition in reducing urban pollution.

\section{Materials and methods}

This paper aims to analyze the disparities between Romanian counties concerning urban population access to sanitation services. First of all, it is performed a comparative analysis between the years 2003 (pre-accession) and 2008 (postaccession) on share of urban population without access to sanitation services. These data were processed and mapped using the color range (for percentage values) and circles proportional method (for absolute values - number of people).Absolute values are designed to complete and to help in more accurate interpretation of percentage values because of the demographic disparities existing between the Romanian counties. High share of urban population without access to sanitation services (or the large number of inhabitants) leads to illegal dumping of waste generated and 
uncollected in urban areas. It performs an analysis of urban areas vulnerability to waste pollution.Furthermore, it can estimate the amounts of urban waste generated and uncollected at county level (Mihai et al.,2011).The differences existing between the years 2003 and 2008 are explained by the fact that since 2003 it has been introduced new methods for processing statistical data from waste operators. In this context, the relevant statistical data has improved from year to year, data from the 2008 being more reliable than 2003.

The first data come from the regional waste management plans developed in 2003 (pre-accession period), these plans being the basis of reference for developing the local waste management plans (county level). Also ,these plans were reviewed during 2006-2008. On the other hand, it is noticed that in the period 2003-2006 several rural villages (lack of waste collection services) were declared cities shifting the share of urban population served by such services. Spatialtemporal analysis was based on data concerning the share of urban population served by sanitation services for Romanian counties in the period 2003-2008. These data were provided by the 8 Regional Environmental Protection Agencies and processed using multivariate analysis such as ascending hierarchical cluster analysis. Thus, counties were divided into 7 typological classes, and each class has been related to Romanian average. Classes profile is expressed in standard deviations being supplemented by charts that illustrate the multiannual average (arithmetic) of classes and the Romanian average, highlighting the territorial disparities between counties.

\section{Results and discussions}

The urban population without access to sanitation has the lowest values $(<10 \%)$ in counties with a lower share of rural population (Tulcea, Brăila, Galați) or where urban population is concentrated in large cities of Romania from Constanța, Braşov and Timiş counties, sanitation services are extended reducing the illegal dumping .

In contrast, counties with high share of urban population (20-40\%) without access to sanitation services are the most vulnerable to waste pollution (Prahova, Suceava, Hunedoara, Buzău, Alba etc) (Fig. 1).

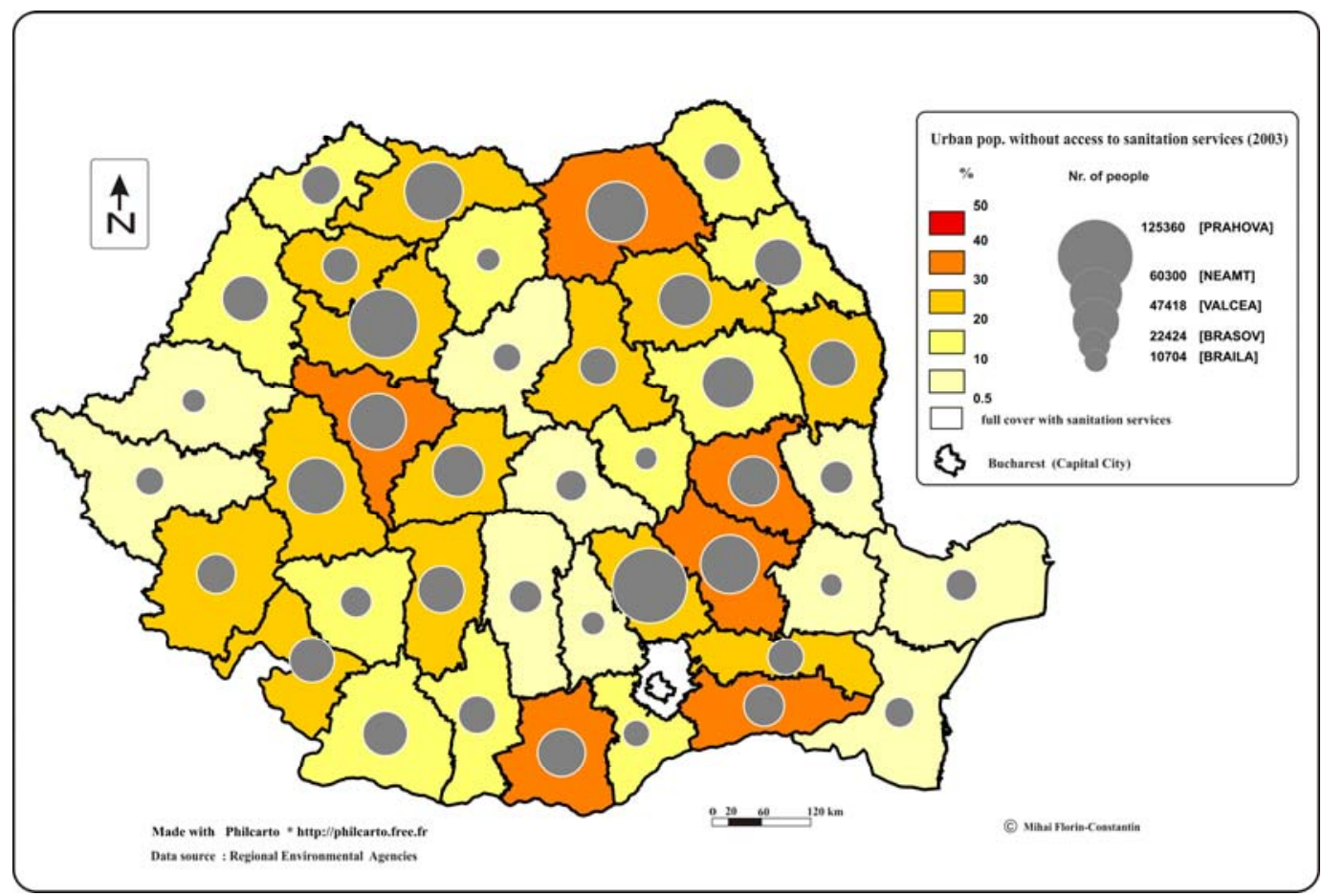

Fig.1 Spatial analysis of urban population without access to sanitation services in 2003

Furthermore, small and middle cities do not have regular waste collection services and disposal is done on dumpsites from proximity. In 2003, cities (over 100000 inhabitants) provided waste collection services on a regular schedule but with an old infrastructure. The largest amount of waste generated and collected from the population were disposed in noncompliant landfills and only certain streams of recyclable waste (metal, paper, cardboard and plastic) were valued by economic agents.Sanitation services and management of landfills belonged mostly to the local authorities, the private capital was poorly developed for collection, transport and landfill of household waste and only in the recycling process has outlined a certain economic market. 


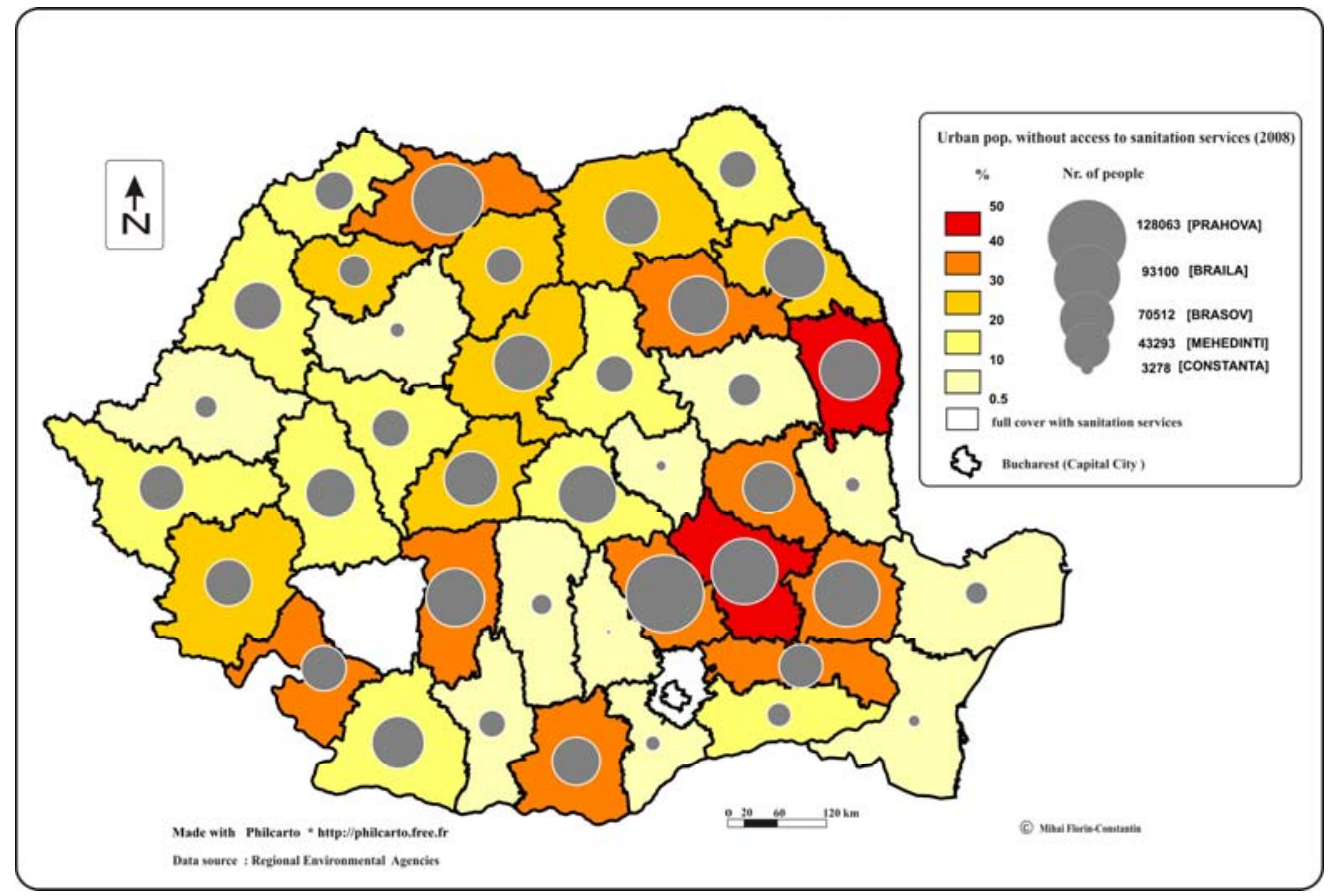

Fig.2 Spatial analysis of urban population without access to sanitation services in 2008

In 2008, one year after the accession of Romania in the EU, the regional disparities on access to sanitation services were pronounced.However, comparative analysis between from pre-accession period (2003) and the post-accession (2008) reflected some trends of urban population without access to sanitation services:

- Prahova county continues to have the most urban residents without access to sanitation services (128063 inhabitants in 2008);

- In two counties, Vaslui and Buzău, the range of urban population without access to sanitation services is over 40\% (41.1\% - 75120 inhabitants respectively $45.11 \%$ - 90030 inhabitants) higher than in 2003;

- High growth of urban population unserved in Brăila from 5\% (1074 inhabitants) to $39.35 \%(93100$ inhabitants);

- Significant increases highlighted in Neamț, Călăraşi, Maramureş, laşi, Mureş and Vâlcea counties;

- Full coverage of sanitation services in Bucharest city, llfov and Gorj county;

- Significant decrease in urban population without access to sanitation services in Cluj county from $23.2 \%$ (105204 inhabitants) in 2003 to $1 \%$ (4626 inhabitants) in 2008;

- descending trend (since 2003 ) for counties with a share less than 10\%: Constanța, Tulcea, Dâmbovița counties.

- Minor changes compared to 2003 for Botoşani, Satu Mare, Bihor, and Harghita counties, suggesting that development of sanitation services in urban areas have been insignificant during the analyzed period. 


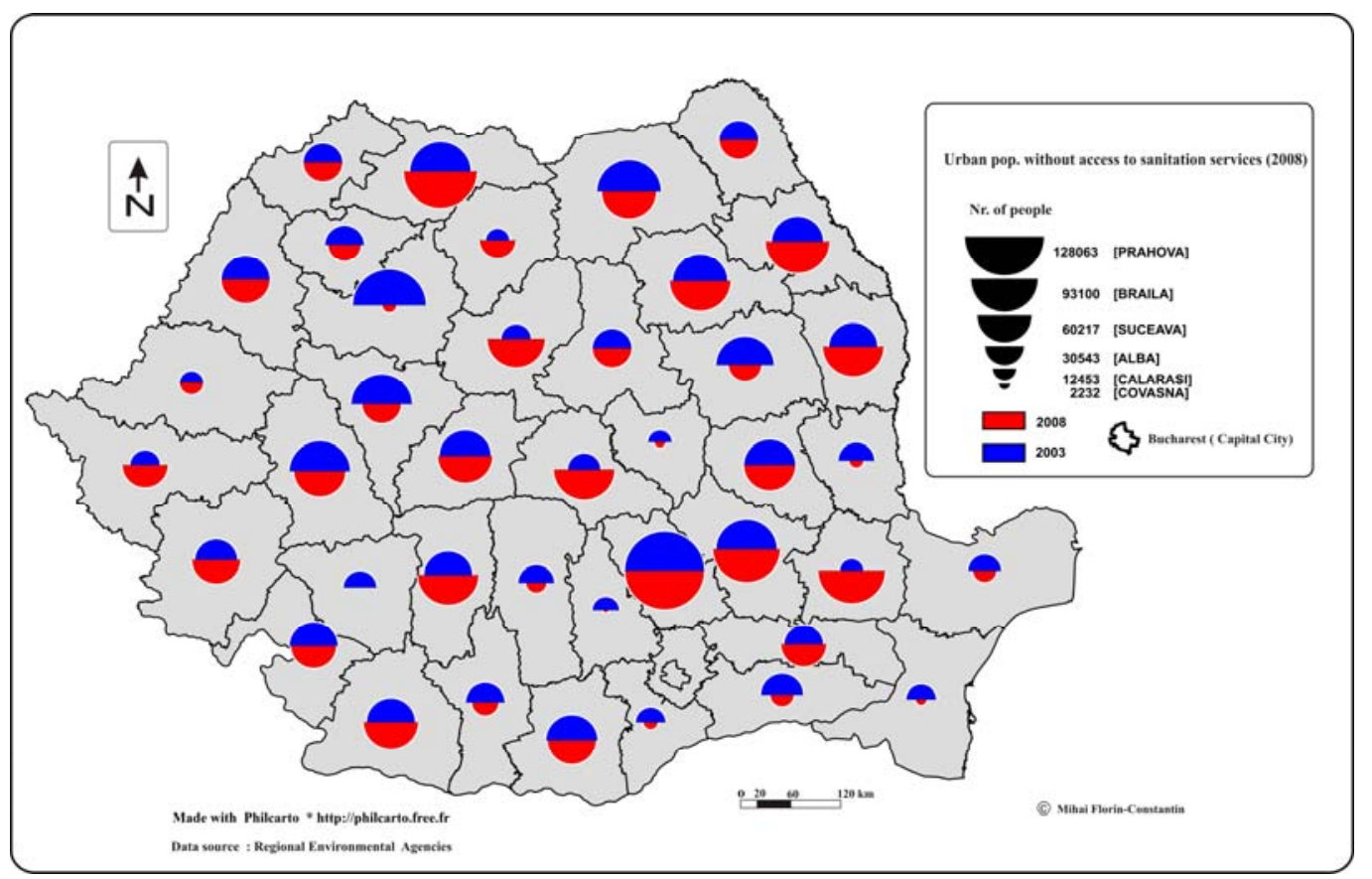

Fig.3 Comparative analysis between 2003 and 2008

Unlike 2003, along the adoption of the EU acquis which includes specific regulations for municipal waste streams (packaging waste, WEEE, ELV, batteries and accumulators, hospital waste, etc.) it has developed the private sector in waste management.Furthermore, in largest cities sanitation services are provided by several waste operators (public and/or private). Pre-accession PHARE and ISPA funds have led to the implementation of integrated solid waste management systems in cities (e.g. Piatra Neamt). At the end of the year 2008 in Romania were operating 20 sanitary landfills from 12 counties. The transition from the traditional system (based on mixed waste collection and often disposal in non-compliant landfills) to a system that stimulates the separate collection, recycling, waste recovery and ultimately disposal in sanitary landfills is a complex and difficult process in the context of partial access of urban population to sanitation services.Development and full coverage of population with such services is a key factor in improving the urban environment and quality of life. All open dumps inventoried by local authorities from small and middle cities should be closed and rehabilitated until July 16, 2009 as well as dumpsites from rural areas being subject to the same environmental obligations (Apostol and Mihai,2011).Theoretically, following this date, local authorities are obliged to provide the collection of all urban waste generated. Closure of non-compliant dumpsites from small and middle cities leads to increased cost of waste collection services due to the transport to active urban landfills. Unfortunately, maps and field observations confirm that the issue of waste collection is far from being solved. However, local waste management plans provide the development of waste management systems to serve the rural and urban areas. In small and middle cities are built transfer stations that will serve rural areas from proximity. Separately collected waste will be composted or sorted and the rest which cannot be reused will be disposed in a sanitary landfill. 


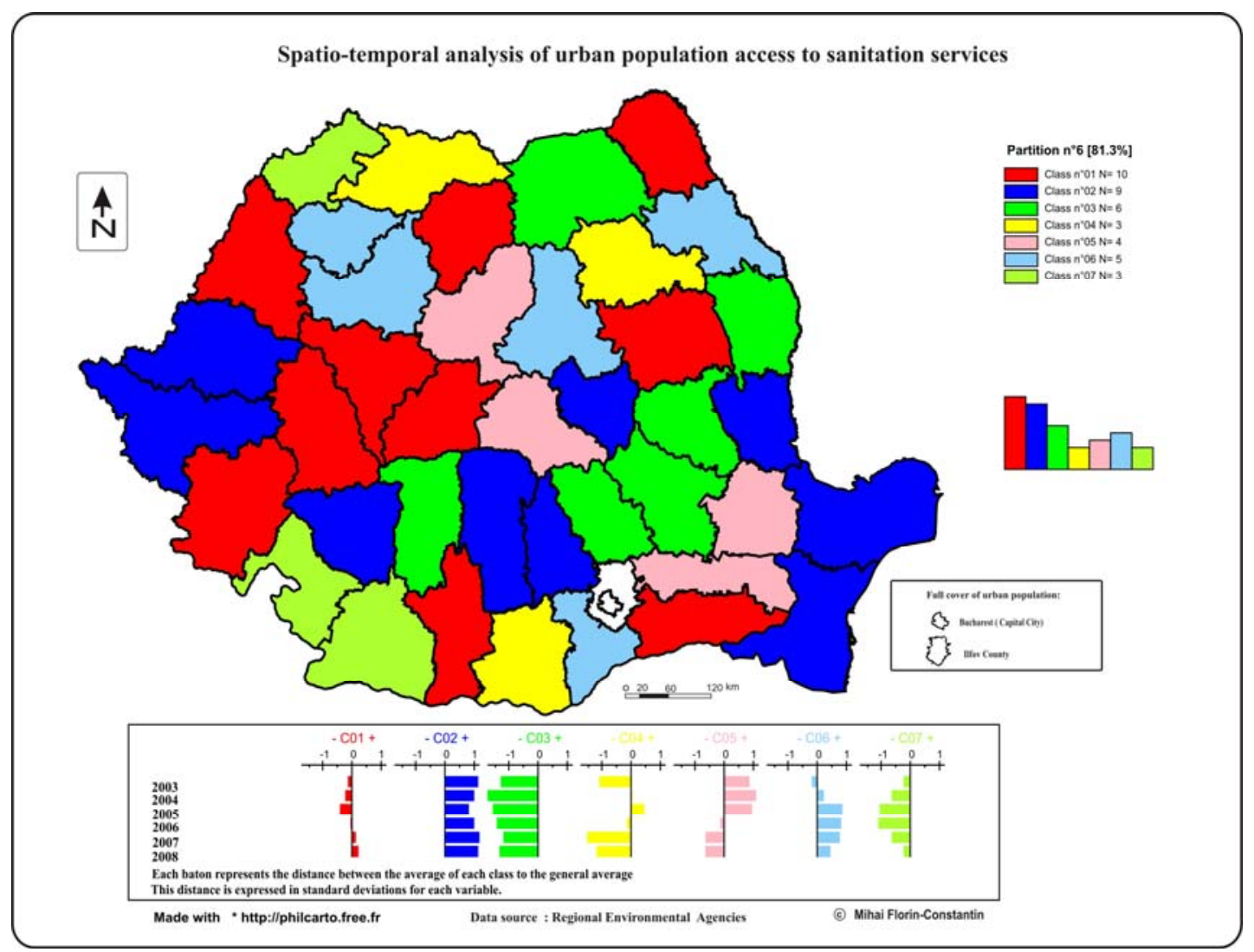

Fig.4 Spatial - temporal analysis of urban population access to sanitation services

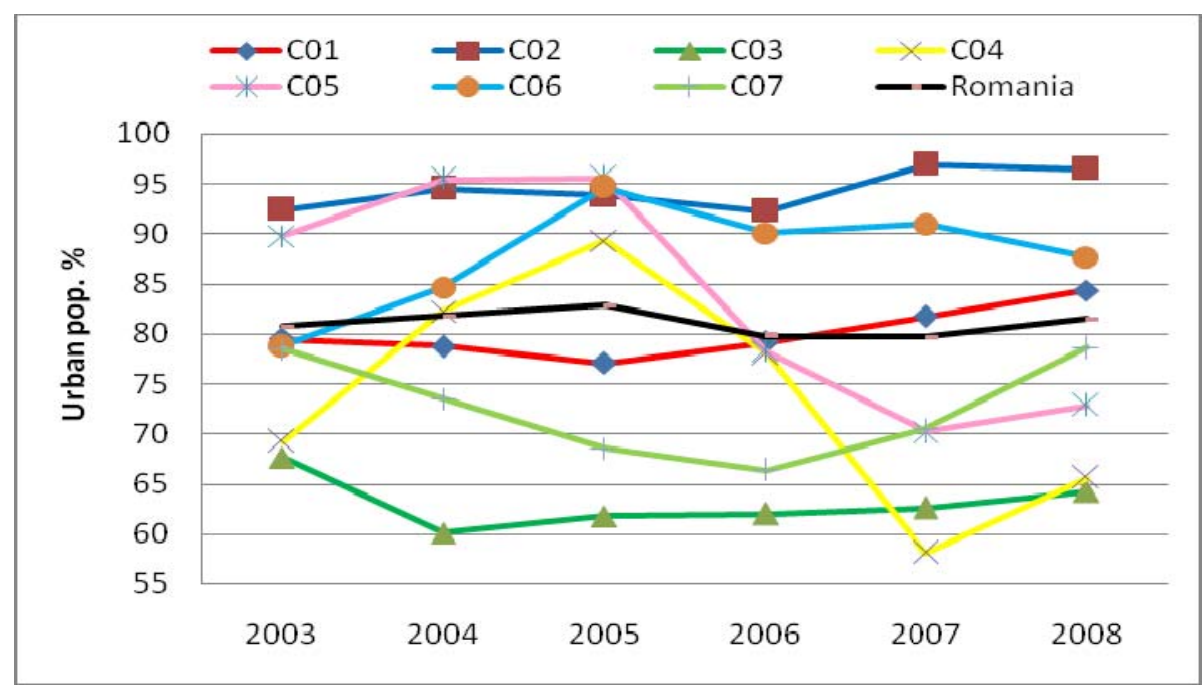

Fig.5 Multiannual average of classes related to Romanian average

Romanian counties were divided into the following classes using ascending hierarchical cluster analysis on urban population access to sanitation services:

- Class 1 - includes counties close to the Romanian average concerning the share of urban population connected to sanitation services, values between $75-80 \%$ in the period $2003-2006$ and a slight increase over general average by 2008;

- Class 2 - includes counties with high share of population served by waste collection services over the Romanian average highlighting a growing trend in 2007-2008. Cities from these counties are least vulnerable to illegal dumping, waste collection services was well developed on whole period considered. It is noticed that the share of urban population from these counties is significant (Constanța, Timiş, Galați, Tulcea); 
- Class 3- urban population of these counties has limited access to sanitation services being the most vulnerable to waste pollution Sanitation services cover an average $60-65 \%$ of the population. Thus the generated and uncollected waste are inappropriate disposed.In the period 2004-2007, several rural localities (without sanitation services) have been declared cities reducing the share of urban population for some counties such as Suceava. Because of lower standard of living and limited budget of local authorities, small cities cannot afford the full access of population to sanitation services or to sign contracts with private sector.Household waste are mixed collected by informal sector and disposed in open dumps located on the outskirts of cities or in nearby villages. Furthermore, in Vaslui and Vrancea counties the situation is critical because in 2008 waste collection services did not exist in rural territory (Apostol and Mihai,2012). The urban population in these counties is the most exposed to illegal dumping ,polluting the environment due to a rudimentary waste managemnet infrastructure.

- Class 4 - this class has oscillating values with following trends : an increasing trend mainly in 2003-2005, followed by a suddenly decrease in 2007 and another increasing trend in 2008. The quality of data reported by sanitation operators to Environmental Protection Agencies is questionable; the values for the last few years are more reliable. In this context, values of 55-65\% in 2007-2008 for Neamt, Maramureş and Teleorman counties are much lower than 2003 and also lower than counties from class 3 , revealing an inadequate waste management such as open dumping. Also, the situation is more critical in Teleorman county due to the lack of waste collection services from rural territory in 2008, taking into account thet fact rural population is larger than urban (Apostol and Mihai,2012). However, inside the counties there are disparities between the larger cities (often county capitals) and midlle or small cities. Since 2007, an integrated solid waste management system was implemented through ISPA funds in Piatra Neamt city (from Neamț County) corresponding to EU standards. This system includes separate collection of waste (paper, cardboard, plastic, biodegradable and residual) sorting and composting plant, crushing plant for construction and demolition waste, sanitary landfill. In 2007, in the same county, $20 \mathrm{~km}$ away from Piatra Neamt, city, Roznov city had no access to sanitation services, waste generated being uncontrolled disposed in open dumps or on Bistrița river bank. These local disparities are common between major cities and midlle or small ones.

- $\quad$ Class 5 - The share of urban population with access to waste collection services had a continuous descending trend from high values in 2003-2005 (over $90 \%$ ) to below values (75\%) in 2007-2008. This decrease may be explained due to improvement of quality data reported by waste operators and because of the new methodology adopted on waste statistics. This class includes counties with a significant share of urban population such as Braşov and Brăila. Also, there are major differences concerning waste management between county capitals and small cities.(e.g.Braşov-Rupea).The urban areas are prone to illegal dumping.

- Class 6 - high share of urban population served by sanitation services, above the Romanian average, in the period 2004-2008, with maximum value in 2005 (95\%) followed by a slight decrease in 2008 (87\%). In this class belong Cluj and laşi counties whose capitals (laşi and Cluj-Napoca) are implementing an integrated urban solid waste management system in accordance to Eu acquis.

- Class 7 - includes 3 counties (Mehedinți, Dolj and Satu Mare) the share of urban population access to sanitation services is lower than the Romanian average for the entire period analyzed, gradual decreasing in 2003 to 2006, (from $78.5 \%$ in 2003 to $66.38 \%$ in 2006), these decreases being recovered during the last two years (2007-2008).

\section{Conclusion}

Spatial-temporal evolution of sanitation services is not positive and linear, on the contrary, has many oscillations. Data on urban population access to sanitation services are more reliable in the past three years (2006-2008) due to improved methods of waste statistics. These overestimated data are explained by the significant declines in some counties in the period 2003-2005. In the period 2004-2007 several rural localities (without sanitation services) have been declared cities, which has led to decreasing share of urban population served by sanitation services (Suceava, Piatra Neamț). However, there are major disparities in the urban population access to sanitation services in the Romanian counties. Larger cities of Romania (laşi, Cluj, Constanța, Timişoara) influences positively the share of urban population with access to sanitation services for the counties they belong (laşi, Cluj, Constanța, Timiş). Urban territories of counties from following classes 1 , $3,4,7$ (26 out of 41 counties) are most vulnerable to illegal dumping, the extension of sanitation services being absolutely necessary. In 2008 along Bucharest (capital city), only in 2 counties (llfov and Gorj) urban population were full covered with sanitation services and in 11 counties the access to sanitation services was below $10 \%$. The situation from 2008 highlights the fact that waste collection services from urban areas is still an unsolved issue. Hosehold waste generated and uncollected are often uncontrolled disposed in open dumps on the outskirts of cities or working-class 
districts. Furthermore, small and middle cities still have a rudimentary waste management system.Implementation of integrated solid waste management systems for each county will lead to an extension of sanitation services in urban and rural areas.

Acknowledgments: This work was supported by the European Social Fund in Romania, under the responsibility of the Managing Authority for the Sectoral Operational Programme for Human Resources Development 2007-2013 [grant POSDRU/CPP 107/DMI 1.5/S/78342].

\section{References}

Apostol L., Mihai F.C.,(2012), Rural waste management: challenges and issues in Romania. Present Environement and Sustainable Development, 6 (1), in press.

Apostol,L., Mihai, F.C.,(2011), The process of closing down rural landfills Case study : Neamt county, Present Evironment and Sustainable Development, 5 (2), 167- 174

Chen, C.C.,(2010),Spatial inequality in municipal solid waste disposal across regions in developing countries. Int. J. Environ. Sci. Tech., $7(3), 447-456$.

Dahlén, L., Vukicevic, S., Meijer, J.E., Lagerkvist, A., (2007), Comparison of different collection systems for sorted household waste in Sweden. Waste Management, 27, 1298-1305.

Firdaus, G., Ahmad, A., (2010), Management of Urban Solid Waste Pollution in Developing Countries. Int. J. Environ. Res., 4, 795-806.

Gellynck, X., Verhelst, P., (2007), Assessing instruments for mixed household solid waste collection services in the Flemish region of Belgium. Resources, Conservation and Recycling, 49, 372-387.

Gurdal, K., (2010), Municipal solid-waste management in Istanbul, Waste Management,30, 1737-1745.

Marques R.C., Simoes. P., 2008, Does the sunshine regulatory approach work? Governance and regulation model of the urban waste services in Portugal. Resources, Conservation and Recycling, $52,1040-1049$.

Mengozzi, A., (2010), Waste Growth Challenges Local Democracy. The Politics of Waste between Europe and the Mediterranean: a Focus on Italy, California Italian Studies Journal, 1(1), 1-21 (http://escholarship.org/uclitem/53v28242)

Mihai, F.C., Ghiurcă, A., Lămaşanu, A., (2011), Estimation of urban waste generated and uncollected in Romania, Analele Universitățiii Oradea, Fascicula: Protectia Mediului, 17(2),719-724

Ventosa, P.I., (2008), Charging systems and PAYT experiences for waste management in Spain, Waste Management, 28, 2767-2771. 